\title{
Regular Feature
}

\section{Hotels}

\section{Hotel Management Contracts in Europe}

Received (in revised form): 5 January 2007

\section{Elana Bader}

is an Associate with the London office of HVS International, specialists in hotel valuation and consultancy. She joined the firm in September 2005 after having worked for six years in various operational hospitality roles in Europe and the USA. Originally from Zürich, Switzerland, she holds a Bachelor of Science in Hotel Administration from Cornell University. Since joining HVS International she has conducted several valuations, market and financial feasibility studies in Europe and the Middle East, as well as written several articles covering European hotel transactions in 2005, the Budapest and Bucharest hotel markets, and sustainable business practices in hotels.

\section{Amir Lababedi}

is an Associate with the London office of HVS International. He joined the firm in October 2005 after having worked in the hospitality industry for over ten years. Amir holds a Bachelor of Science (Hons) in Hotel Management from the University of Surrey. He joined the family hotel investment business in 2001 in which he worked for three years before acquiring his MSc in Global Banking and Finance in 2005 from the European London Business School. Since joining HVS International, Amir has provided hotel investment advice and conducted valuations and feasibility studies in numerous countries within Europe, Africa and the Middle East.

\section{Abstract}

This article reviews the main terms, definitions and applications of a typical European hotel management contract. It must be noted that the terms and definitions provided below are broad indications only and that any of these terms can vary significantly depending on factors such as asset class, location, brand operator and investor type.

\section{Keywords:}

risk, hotel owner, hotel operator, management contracts

Journal of Retail and Leisure Property (2007) 6, 171-179. doi:10.1057/palgrave.rlp.5100053

Elana Bader HVS International 7-10 Chandos Street Cavendish Square London $\mathrm{W}_{1} \mathrm{G} 9 \mathrm{DQ}$, UK Tel: +44 (o) 2078787710 Fax: +44 (o) 2078787799 E-mail: ebader@hvsinternational. com

\section{INTRODUCTION}

A hotel management contract, also known as a management or operating agreement, is an arrangement whereby a hotel's owner contracts with a separate company, or an operator, to run a hotel. By doing so, the owner retains limited control over the operation of the asset often through measurable performance standards albeit that the owner retains more risk than if the hotel were leased to the operator. 
An operator, or hotel management company, hired to run a hotel business will provide supervision, expertise, established methods and procedures and normally also a track record of verifiable past performance. The operator runs the hotel for a fee according to specified terms negotiated with the owner; the most common of these terms are described below in more detail. Such an agreement generally aims to maximise the return on investment (ROI) for both the operator and the owner (typically an 'investor owner'), places the operational risk of profit and loss on the owner and can affect the asset value in a positive or negative way depending on the quality of the operating company and market conditions.

As a result of a gradual shift in hotel investment trends over the past 20 years, owners have developed a much greater understanding of the hotel operation, and have become more sophisticated in their selection of operators and in the negotiation of contract terms, often with the help of specialist advisery firms. It has become increasingly common in recent years for institutional and financial investors and private equity funds to invest in hotel assets. Such investors typically aim to separate ownership of the physical hotel asset from operation of the business. In addition, the investment interest and associated increase in the amount of capital available for hotel investment from this wider pool of investors has further contributed to the increased sophistication of hotel investors, who often have in-house hotel asset managers or engage specialty consultancies or asset management companies to obtain peak performance from the operator.

The second major influence on the evolution of management contracts in Europe has been driven by the continued consolidation and globalisation of the industry. This expansion of major global brands into Europe has inevitably led to an increase in competition among operators, and has consequently led to the 'balance of power' shifting more towards the owner rather than the operator, whereas the reverse has historically been the case.

\section{MANAGEMENT CONTRACT TERMS}

A typical hotel management contract consists of a mix of commercial and legal terms. Some of these terms have an immediate and lasting effect on the likely cash flow to the owner and the performance and manageability of the selected operator. We have highlighted the following terms, which are described in more detail below.

- Term

- Operating Fees

- Operator Guarantees

- Performance Measures

- Owner Approval

- Capital Expenditure

- NonCompete Clause

- Dispute Resolution

- Termination, including Early Termination. 


\section{TERM}

The initial term of a management contract is the length of time that the agreement is to remain in effect. Initial terms usually last ten, 15 or 20 years, depending on the brand and positioning of the operator selected. Well-respected upscale operators, such as Four Seasons Hotels \& Resorts and Ritz-Carlton, can generally command much longer initial contract terms of the order of 50 years.

Renewal terms generally extend the total length of an initial term. This is commonly done by mutual consent and is rarely unilateral. In general, renewal terms occur in multiples of five years, occasionally ten. Most contracts offer two terms (sometimes more) on the condition that six months' written notice is given prior to the end of the current term.

There has been a noticeable decrease in the average length of initial terms across Europe from a historical average of 20 years towards a current average of 15 years. This shift can be attributed to the following factors.

- An increase in hotel investment in emerging markets, such as those in Central and Eastern Europe, and the associated risks, have led both owners and operators to negotiate contracts with shorter initial terms in order to provide the opportunity to exit in the event of disappointing market conditions.

- The proliferation of private equity vehicles in the hotel investment arena in recent years has placed pressures on operators to offer more competitive, shorter initial terms but with more renewal options.

- Increasing competition among hotel operators seeking to broaden their distribution network.

\section{OPERATING FEES}

An operator will typically receive remuneration from the owner, often termed a base fee, in exchange for performing the duties specified in the contract. Base fees typically range from 2 to 4 per cent of the total revenue.

In addition to the base fee, an operator usually receives an incentive fee based on a percentage of profits. This may be curtailed, for example, until profitability reaches a certain threshold, or until minimum return requirements to the owner are met (typically related to debt service). These incentive fees are typically related to one of the following:

- Gross operating profit (GOP) before the deduction of base management fee (although this is rare).

- Adjusted GOP (calculated by deducting the base management fee from the GOP).

- Net operating profit (NOP) after deduction of some or all fixed charges, for example building insurance, property taxes, reserve for replacement of furniture, fixtures and equipment (FF\&E), or rents payable.

- NOP after deduction of some or all fixed charges and an owner's priority return. In this event, the percentage fee payable to the operator is sometimes higher. 
A growing number of operators accept lower base fees in return for higher incentive fees of up to 15 per cent of GOP, which are intended to reward operators more generously for outperforming agreed targets.

While a set incentive fee of about 10 per cent of GOP was typical, it is becoming increasingly common to have scaled incentive fees.

The tendency towards higher or scaled incentive fees versus higher base fees not only rewards effective operators but also increases the proportion of free cash flow to equity in the event of poor operator performance.

Other fees and charges typically relate to contributions to the operator in respect of, inter alia, reservation systems, sales and marketing contributions or assessments, accounting charges, purchasing costs, and license or franchise fees. These fees are often set as a percentage of rooms' revenue, and typically range from 1 to 4 per cent of gross rooms' revenue.

\section{OPERATOR GUARANTEES}

An operator guarantee ensures that the owner will receive a certain level of profit. In the event that this level of profit is not achieved by the operator, the operator guarantees to make up the difference to the owner through their own funds. For example, if the contract states a guarantee of $€ 1,000,000$ per annum and the operator achieves only $€ 800,000$, then the operator will make up the remaining $€ 200,000$ from his/her own funds.

It is typical when such guarantees exist that there is a provision for the operator to 'claw back' any payments made under a guarantee out of future surplus profits. Equally typical is the tendency for the operator to place a limit ('cap') on the total guaranteed funds within a specified number of years.

Operator guarantees are not to be confused with owner priority returns, which reflect a hurdle of a particular performance (such as GOP) to the incentive fee. For example, if the owner priority return is equal to $€ 1,000,000$ and the GOP achieved in a particular year is $€ 800,000$, then the operator will not receive an incentive fee. If the GOP in a particular year is $€ 1,200,000$, then the incentive fee will be payable.

Where the operator fails to receive an incentive fee, this is sometimes referred to as a 'stand aside'. Some contracts allow for this to be paid once future profits are earned to cover the shortfall.

The current trend is for a shift away from operator guarantees. Since the events of September 2001, operators have been placing limits on guarantees to exclude force majeure factors in order to cover their future liability. In addition, the various public company scandals in recent years, such as Enron, have led to more caution among listed hotel groups taking on liabilities that are dependent on the performance of other parties. As such, operators will generally require higher fees in return for an operator guarantee and this may not always be cost-effective for the owner. In addition, most contracts will include a cap on the level of operator guarantee, as noted above. 


\section{PERFORMANCE MEASURES}

There are typically two types of performance tests, and both are often used jointly as follows:

1. Room revenue per available room (RevPAR) of the subject hotel as a percentage of a mutually agreed competitive set.

2. If the GOP achieved for an operating year is less than a pre-agreed percentage of GOP.

Some experts consider that RevPAR is not always a reliable performance measure. Unscrupulous operators can artificially inflate RevPAR performance to meet the required standards as such a criterion (RevPAR) might tempt the operator to focus on the revenue line at the expense of profit margins.

Should a force majeure or some other similar event happen that is beyond the operator's control, then the performance test may not be applicable for that year.

Default at the hand of the operator is usually possible only if either or both tests have been failed over two consecutive years. A performance test frequently commences only from the performance stabilisation of the hotel.

Usually the operator negotiates a 'right to cure' clause, allowing for the payment of funds to achieve minimum GOP. This 'right to cure' can be restricted by the owner to allow termination of the agreement.

\section{OWNER APPROVAL}

Approval clauses set out the extent to which the consent of the owner is required for decisions affecting the operation of the hotel. These typically include budget, employment of key management positions, outsourcing, capital expenditure, and leases and concessions.

This allows the owner to remain involved with key decisions that could affect cash flow and also allows for cost transparency. In addition, if stipulated, an owner can place restrictions on expenditure (for example, those relating to purchasing systems, concessions or leases).

Owner approval of the annual budget is usually negotiated, but such an approval may depend on the conditions of the performance test, and may therefore exclude certain line items.

If a dispute occurs, a dispute procedure is commenced, ending in an arbitration process with an independent expert.

An operator has the responsibility of hiring and training the line-staff personnel. In a significant proportion of management agreements, owner approval is only required for the hiring of senior management, such as the general manager, financial controller or director of sales and marketing. In most cases, the owner remains the employer of the hotel's staff. This enables continuity of employment — and the hotel's operation — in the event that the contract is terminated. Some senior management may be employed by the operator with the payroll for those staff being charged back to the hotel operation. 
An outsourcing clause affects the decisions involving the appointment of an external service provider in relation to the hotel's operations, such as housekeeping or engineering services. The terms of such contracts are usually no longer than 12 months. Owner's consent is rarely required, unless the contract is significant and above a certain hurdle amount (similar to capital expenditure, where consent is required) or for longer than 12 months.

Leases and concessions relate to the leasing out of hotel space to third parties, such as restaurants, spas, gift shops, beauty salons or retail outlets. Most owners will require restrictions on such agreements as perpetual agreements or longer-term agreements may complicate a future sale, and may not always be the most profitable use of the space in the first place.

\section{CAPITAL EXPENDITURE}

The $F F \& E$ of a hotel are often exposed to heavy use and must be replaced at regular intervals. Periodic replacement of FF\&E is essential to maintain the quality, image and income potential of a hotel. As such, a 'sinking' fund is set up to accumulate capital for the periodic replacement of FF\&E, typically a percentage of gross revenue. Included in this category are all nonreal-estate items that are typically capitalised rather than expensed, which means they are not included in the operating statement, but nevertheless affect an owner's cash flow. The percentage of FF\&E reserve is somewhat dependent on the positioning of the hotel. In general, however, hotel management agreements typically provide for a reserve for the replacement of FF\&E of 3-5 per cent of total revenue.

Typically, capital improvements are divided into routine capital improvements (which are funded through the FF\&E reserve account), which are required to maintain revenues and profits at their present levels, and discretionary capital improvements (also called ROI capital improvements). These latter capital improvements are investments that are undertaken in order to generate more revenue and profits, such as the conversion of offices into meeting rooms. The latter require owner approval and are in addition to the funds expended from the reserve account.

Within a management contract the obligation falls upon the owner to provide funds to maintain the hotel according to the relevant brand standards. If management elects to postpone a required repair, they have not eliminated or saved the expenditure, but merely deferred payment until a later date. A hotel that has operated with a lower than normal maintenance budget is likely to have accumulated a considerable amount of deferred maintenance. An insufficient FF\&E reserve will eventually negatively impact the standard or grading of a property, and may also lead to a decline in the hotel's performance and its value.

\section{NONCOMPETE CLAUSE}

An integral component of a market area's supply and demand relationship that has a direct impact on performance is the current and anticipated 
supply of competitive hotel facilities. By including a noncompete clause in a management contract, an owner has an assurance that no other property with the same brand is allowed to open within a certain radius of the subject hotel, typically for the whole duration of the agreement or at least for a defined period, in order to minimise or even pre-empt any form of cannibalisation either from the same brand or another brand of the same company. Depending on the location, size of the city and the type of brand, this may vary significantly. More upmarket brands typically have a larger radius than budget and mid-market hotels. Additionally, operators with a larger portfolio of brands may be able to negotiate the exclusion of certain brands, or the exclusion of all brands but for a shorter length of time.

Negotiations for the determination of the noncompete clause may centre on the following:

- those brands that will be included in the exclusion clause

- the term of the exclusion period

- the provision of an impact study to help determine whether there will be a material effect on the hotel's occupancy and/or average room rate arising from the establishment of a similarly branded hotel.

\section{DISPUTE RESOLUTION}

Typical disputes between a hotel owner and the operator may involve the budget, the performance clauses, the capital expenditure required or changes in management. Key dispute terms that need to be considered are listed below:

- Arbitration - that is, when will the arbitration process occur, who will arbitrate, and so forth

- Expenses - who will pay for the dispute process

- Jurisdiction and venue - where will the legal proceedings take place, and which laws and legislations will preside

- Severance.

Disputes may be resolved in several ways, although they are most often resolved through arbitration or an independent expert; in some cases they may also involve the courts.

\section{TERMINATION}

Each party may terminate an agreement for a variety of reasons; typically included are bankruptcy, fraud, condemnation, performance not met and, sometimes, sale. We have focussed on two of these: termination on sale and termination without cause.

Termination on sale provides the owner the opportunity to realise the investment, and sell the hotel unencumbered, therefore potentially achieving a higher sales price, while also offering more flexibility to the owner and any potential investor. There is typically a sliding scale of compensation paid to the operator, usually based on a multiple of average 
annual fees earned. The scale reflects the number of years remaining but is often in the range of one to three times.

Termination without cause is designed to achieve a dignified end to a contract. A similar compensation structure would apply. Many operators are reluctant to accept such a condition and it is rarely incorporated into an agreement that also includes an operator guarantee. When included, this clause allows for the termination of an agreement because of default due to, for example, force majeure.

\section{POWER BALANCE}

The increase in the number of hotel operators and expansion of global hotel brands into Europe has placed pressure on operators to offer more competitive terms to owners. At the same time, owners have become more knowledgeable and savvy when negotiating management contract terms as the increased sophistication of hotel investors has led to a better understanding of hotel operations.

The combined effect has been that the balance of power has largely shifted more in favour of the owner when contracting with many operators. Owners can now negotiate terms that increase their control, flexibility and leverage in the business and finances of operating decisions, while operators face more performance tests and incentives. Owners are increasingly thinking beyond profit and loss and have become more involved in key decisions, although there is still an obligation to limit this to key matters and not to interfere with the day-to-day running of the business.

Notwithstanding this, we consider that the most desirable outcome is to achieve a 'win-win' between owner and operator, with neither suffering from unduly onerous conditions and each party fully appreciating the needs of the other.

\section{SALE AND MANAGE BACK DEALS}

Reducing asset intensity, also known as separating the property ('the bricks') from the operation ('the brains'), has become a key reason for hotel operators divesting of their property interests in today's market. By selling hotel assets with a management contract in place, hotel operators have gained a considerable sum of capital that can be put towards refurbishment of retained assets, used to fund acquisition and development activity in new markets and brands, or that can be returned to shareholders, as well as reducing their exposure to risks associated with asset ownership. In addition, the emergence of property, institutional and private equity investors, as proven by the weight of capital invested in the sector in 2005 and 2006, confirms the increasing acceptance of hotels as a mainstream asset class.

These two developments, along with the compression of hotel property yields, have created a very attractive market for sale and manage back deals. In recent years, a significant proportion of hotel transactions were prominent sale and manage back deals; this trend is expected to continue. 
Another, partly related trend is the emergence of 'manchises', whereby hotel owners engage a hotel operating company for an initial period of time, say three to five years, after which the contract reverts to a franchise contract whereby the owner assumes management responsibility and retains the operator's brand, for which an annual franchise fee is payable. To the outside world there is no apparent change. This is particularly advantageous to help hotel operating companies launch new brands, enabling string operating controls to be made in the initial years as the brand is going through its 'ramping up' period.

\section{LEASE IMPLICATIONS}

Concerns have been raised regarding the theoretical legal interpretation of hotel management contracts and whether they could potentially give the operator sufficient rights to be considered a lessee. This would be an issue in countries that place social and employee obligations on a lessee, such as France or Belgium, or where tax issues come into play, such as in the UK.

According to Bruce Parmley, a partner with law firm Hogan \& Hartson, a management contract would normally only be considered a lease if the operator carries the risk of the business. Management contracts normally clearly state that the agreement is neither a venture, partnership agreement or a lease, thereby ensuring that, from a legal perspective, the agreement cannot be interpreted as a lease.

\section{CONCLUSION}

The increased knowledge of owners and their understanding of market dynamics, together with the surge of brand operators intensifying the competition in today's market through consolidation and globalisation, enable owners to be in a much stronger bargaining position when negotiating management agreements. As such, pressure has been placed on operators to amend agreement terms that were historically in their favour to terms that now favour the owner. Despite this, operators are able to divest their physical assets in order to concentrate on their core competency, which is the operation, not ownership, of hotels, while simultaneously reducing their risk associated with such assets. 